\title{
Features of entrepreneurial economic mind in Russian small eco-business
}

\author{
Ekaterina Zabelina ${ }^{1, *}$, Olga Deyneka ${ }^{2}$, and Maxim Shakhmatov ${ }^{3}$ \\ ${ }^{1}$ Chelyabinsk State University, 129, Bratiev Kashirinykh str., Chelyabinsk, Russia \\ ${ }^{2}$ Saint Petersburg State University, 6, Makarova Nab., Saint Petersburg, Russia \\ ${ }^{3}$ Yti advertising agency, 1b, Troitskaya str, Chelyabinsk, Russia
}

\begin{abstract}
The concept of sustainable development requires entrepreneurs to increase awareness and responsibility for business and society. In this regard, the question of the entrepreneurial attitudes in the economic sphere is of scientific interest. The study $(\mathrm{N}=413)$ reveals the specifics of economic attitudes of the entrepreneurs compared to employees. Business owners more soberly assess consumer behavior in terms of rationality, they are more inclined to invest, more optimistic about their financial future, and they are more competent in financial issues. At the same time, the cognitive economic activity of the entrepreneurs is expressed at the average level; they tend to evaluate the individual's independent achievements in the economic sphere lower, considering them as something ordinary. Four main strategies of the economic behavior of the entrepreneurs were identified: the strategy of economic activity based on financial knowledge, the strategy of high goals combined with low risk and financial optimism, the strategy of earning and spending money, and the strategy of savings and rationality. In general, business owners tend to agree with the idea of the social responsibility of rich people to the poor, which creates the prerequisites for the sustainable development of society.
\end{abstract}

\section{Introduction}

The concept of sustainable development requires entrepreneurs to increase awareness and responsibility for business and society $[1,2]$. In this regard, the question of the features of the entrepreneurial relations and attitudes in the economic sphere is of scientific interest. Since this issue has been studied limited in the literature, this particular study seeks to fill this gap.

Economic mind (consciousness) is more a subject of study of the Russian economic psychology, while the attention of the European psychologists is focused on the phenomenon of economic behavior [3]. The analysis of the works of Russian specialists investigating this phenomenon (O.S. Deyneka, T. V. Drobysheva, T. P. Emelyanova, A. L. Zhuravlev, N.A. Zhuravleva, A.I. Kitov, A.A. Kapustin, A.B. Kupreichenko, S.V. Malakhov, I.M. Osipenko, V.P. Poznyakov, V.D. Popov, T.V. Folomeeva, V.P. Fofanov, V.A. Khashchenko and others), allows us to draw a conclusion about the complexity, diversity, multicomponent

\footnotetext{
*Corresponding author: katya_k@mail.ru
} 
nature of this integral formation, as well as about the ambiguity of the concepts that denote the components of its structure.

By analogy with the definition of consciousness in general psychology, in economic psychology, economic mind can be defined as an integral system of reflection of objective economic reality, consisting of various elements represented in the psyche of an economic subject that are in regular hierarchical relationships with each other. One of the earliest definitions of economic mind in Russian science is given by A.V. Filippov and S.V. Kovalev [4], who interpret it as a systemic component of the consciousness, the highest mental level of reflection of economic relations by a socially developed person.

Of great importance for Russian economic psychology are the socio-psychological studies carried out in the Laboratory of Social and Economic Psychology of the Institute of Psychology of the Russian Academy of Sciences under the direction of A.L. Zhuravlev. All of them study the phenomena of economic mind in one way or another: the phenomenon of self-determination of an individual and a group in the economic environment [5], business activity of the entrepreneurs [6], value foundations of economic socialization [7], intra-group responsibility in labor collectives with different forms of ownership [8], the influence of the attitude to property on the psychology of peasants in the context of socio-economic changes [9] and others.

Within the framework of this direction, the definition of economic mind is formulated, and its structure is presented. Economic mind is understood as a particular form of an individual or a group consciousness, which consists in different forms of knowledge of individual and group subjects about various economic objects and their relationship to this knowledge [10]. The main phenomena of the individual and group economic mind include social representations of economic objects, both real and ideal; attitudes to economic objects, as well as opinions and judgments about them, their assessments, etc.; social attitudes, stereotypes and prejudices associated with economic objects; conscious emotions, feelings and experiences associated with economic objects in general; the phenomenon of social expectations, anticipation, forecast of economic changes, i.e. upcoming events related to economic objects; social categorization and interpretation of economic and psychological phenomena, etc. At the same time, it is emphasized that these phenomena of economic mind do not have any single basis for their isolation, they partially overlap each other in their content and are designated by terms from different theoretical approaches [10].

On the basis of the empirical research Zhuravlev highlights the main components of the economic mind: views (of oneself as an economic actor, of the material welfare, wealth; of the rich and the poor people, of profitable activities, of the property and the owner); social attitudes to different forms of economic behavior; attitude to money; psychological readiness for competition with other people in the economic sphere; the orientation to economic value [11]. The authors emphasize the subject-object nature of economic mind as a result of interaction, on the one hand, of the individual with its numerous individual psychological characteristics, and on the other hand, of the socio-economic environment with its no less numerous features.

The model of economic mind proposed by O.S. Deyneka [12] is characterized by order and logic. The researcher suggests considering the components of economic mind at the intersection of two planes: activity - passivity, reflection function-regulation function. Thus, there are four main quadrants of the economic mind: 1) economic perception, 2) feelings and emotions in the economic sphere, 3) economic ideas and economic thinking, 4) economic motives, interests, norms and economic actions, and activities.

In addition, the scientist identifies relations, attitudes and stereotypes in the structure of economic mind that can be represented at different levels (from image-emotional to verballogical) [12]. These relations, or to use the term of foreign social psychology - attitudes, play, in our opinion, a particularly important role in the structure of the economic mind, as they 
generalize all its levels.

Despite the fact that the term relation is more familiar in Russian economic psychology [e.g., 10], it is proposed to use the term attitude in this study. In Russian science, the concept of attitude is usually identified with the concepts of relation or readiness, but the definition of attitude in foreign interpretation is made with an emphasis on the conative component, namely, that attitudes may determine economic behavior [13, 14, etc.]. The concept of attitude has been widely used in social psychology since the first third of the twentieth century. In a general sense, attitude refers to "a relatively enduring organization of beliefs around an object or situation predisposing one to respond in some preferential manner" [13, p. 112]. Traditionally, the structure of an attitude is divided into three components - cognitive, affective, and behavioral (conative) [14], which are closely interrelated [15], but may also conflict with each other [16].

The economic attitudes of individuals and social groups were most actively studied in the last quarter of the twentieth century. In particular, studies have been conducted on attitudes to unemployment [17], to savings [18], to debt in consumer behavior [19], to money [20], as well as on investment [21] and entrepreneurial attitudes [22].

One of the economic attitudes can be considered the attitude of a person to his personal economic situation, the assessment of his economic well-being. According to the definition of A. Khashchenko, subjective economic well-being is an integral psychological indicator of a person's life, expressing a person's attitude to their current and future material well-being, which is an important component of a person's subjective well-being [23]. This phenomenon can be considered as a subjective criterion of a person's realization in the economic sphere, or his or her economic success. The level of subjective economic well-being can be diagnosed by the subjective assessment of the income level - satisfaction with income level [e.g., 4].

The elements of the economic mind of the entrepreneurs are limited studied. Traditionally, entrepreneurial characteristics include independence [24], self-reliance [25], responsibility [26], self-control [27], riskiness [28], absorptive capacity [29], innovation [28], proactivity [28], and related attitudes. But this list could be changed due to the changeable environment.

Thus, the study purpose is to identify the features of the economic attitudes of the entrepreneurs - owners of small businesses in comparison with hired employees. Additionally the structure of the economic attitudes of the entrepreneurs was studied.

\section{Materials and methods}

A total of 413 responders participated in the study, including 109 representatives of small businesses in various fields of activity (wholesale and retail trade, education, tourism, consulting, manufacturing, etc.) working in Russia (in the city of Chelyabinsk and Chelyabinsk region). This group was formed randomly and included respondents aged 24 to 68 years (average age 34.9 ), $42 \%$ male.

To identify the features of the economic mind of the entrepreneurs, a control group of employees working for hire from various fields of professional activity was formed:

1. IT specialists of commercial organizations (programmers, developers, system administrators) - 111 people aged 19 to 45 years (mean age 26.4 ), 58.5\% male.

2. Employees of state institutions (secondary schools teachers) - 102 people aged 23 to 62 years (mean age 37.5$)$, 25.5\% male.

3. Civil servants (officials, the representatives of the city administration, legislative assembly, judges) - 92 people aged 23 to 65 years (mean age 37.1 ), $43.5 \%$ male.

When determining and forming groups of the respondents, the logic of contrasting characteristics of professional groups was maintained: 1) entrepreneurs vs hared workers; 2) employees of commercial companies vs employees of budgetary (state) institutions. Civil 
servants are chosen as the most striking contrast to entrepreneurs group, as it represents a certain category according to the Russian legislation. First, civil servants are forbidden to engage in their own business, second, work at the civil service is relatively stable and predictable; third, their activities are strictly regulated, therefore, it gives a modest place to risk and creativity. All these characteristics of professional activity are opposed to entrepreneurship, where risk, uncertainty, and creativity come first. Among the commercial organizations, companies working in the field of information technology were selected, since this direction is actively developing now and brings high revenues to companies.

To analyze the peculiarities of the economic mind, the "Questionnaire of Economic Attitudes" [22] was used. This questionnaire comprehensively characterizes the field of economic attitudes of a personality; it included various spheres of the economic behavior of the owner (attitude to money, property, saving and investment behavior), the consumer, the entrepreneur, and the employee.

\section{Results and Discussion}

At the first stage, we compared the economic attitudes of the entrepreneurs and employees from various fields of activity. The results of comparison of the economic mind of the entrepreneurs and employees are presented in Table 1.

Table 1. Results of comparative analysis of the economic mind of the entrepreneurs and employees.

\begin{tabular}{|c|c|c|c|c|c|c|}
\hline \multirow[b]{2}{*}{ Indicators } & \multicolumn{4}{|c|}{ Mean rank } & \multirow[b]{2}{*}{$\mathbf{H}$} & \multirow[b]{2}{*}{$\mathbf{p}$} \\
\hline & $\begin{array}{c}\text { Entrepr } \\
\text { eneurs }\end{array}$ & $\begin{array}{c}\text { IT } \\
\text { professionals }\end{array}$ & $\begin{array}{c}\text { School } \\
\text { teachers }\end{array}$ & $\begin{array}{c}\text { Civil } \\
\text { servants }\end{array}$ & & \\
\hline $\begin{array}{l}\text { rationality of } \\
\text { purchases }\end{array}$ & 168.67 & 198.83 & 252.22 & 212.20 & 27.7 & .000 \\
\hline $\begin{array}{l}\text { consumer } \\
\text { satisfaction }\end{array}$ & 232.47 & 213.89 & 174.83 & 204.14 & 13.2 & .004 \\
\hline tendency to savings & 191.64 & 205.68 & 231.75 & 199.26 & 6.99 & .072 \\
\hline $\begin{array}{l}\text { confidence in the } \\
\text { future through } \\
\text { savings }\end{array}$ & 202.51 & 221.71 & 204.10 & 197.69 & 2.53 & .469 \\
\hline financial literacy & 220.64 & 216.15 & 180.13 & 209.62 & 7.63 & .054 \\
\hline consumer activity & 197.06 & 228.83 & 210.8 & 188.03 & 7.08 & .070 \\
\hline $\begin{array}{l}\text { willingness to } \\
\text { invest }\end{array}$ & 244.29 & 211.64 & 187.14 & 178.94 & 19.24 & .000 \\
\hline $\begin{array}{l}\text { activity and } \\
\text { rationality in the } \\
\text { banking sector }\end{array}$ & 208.61 & 221.27 & 192.57 & 203.84 & 3.34 & .343 \\
\hline distrust of banks & 214.22 & 201.75 & 193.74 & 219.61 & 2.96 & .397 \\
\hline $\begin{array}{l}\text { cognitive economic } \\
\text { activity }\end{array}$ & 206.29 & 186.76 & 203.84 & 236.08 & 8.88 & .031 \\
\hline $\begin{array}{l}\text { value of } \\
\text { independent } \\
\text { economic } \\
\text { achievements }\end{array}$ & 208.97 & 183.36 & 228.47 & 209.42 & 10.01 & .019 \\
\hline $\begin{array}{l}\text { economic } \\
\text { ambitions }\end{array}$ & 221.17 & 225.00 & 186.98 & 190.52 & 8.96 & .030 \\
\hline $\begin{array}{l}\text { negative attitude } \\
\text { toward } \\
\text { entrepreneurs }\end{array}$ & 186.14 & 218.56 & 222.51 & 200.49 & 6.62 & .085 \\
\hline real estate activity & 225.87 & 196.33 & 195.35 & 210.46 & 4.77 & .190 \\
\hline financial optimism & 262.11 & 226.24 & 161.21 & 168.86 & 51.88 & .000 \\
\hline
\end{tabular}




\begin{tabular}{|l|c|c|c|c|c|c|}
\hline $\begin{array}{l}\text { priority of earnings } \\
\text { over vocation }\end{array}$ & 157.42 & 215.42 & 222.53 & 238.71 & 28.24 & .000 \\
\hline $\begin{array}{l}\text { significance of } \\
\text { financial status }\end{array}$ & 207.55 & 227.68 & 195.58 & 193.92 & 5.52 & .137 \\
\hline $\begin{array}{l}\text { awareness of } \\
\text { consumer } \\
\text { irrationality }\end{array}$ & 217.30 & 204.83 & 205.94 & 198.50 & 1.43 & .700 \\
\hline $\begin{array}{l}\text { investment } \\
\text { illiteracy }\end{array}$ & 204.91 & 211.50 & 207.7 & 203.20 & .296 & .961 \\
\hline $\begin{array}{l}\text { social } \\
\text { responsibility of } \\
\text { wealth }\end{array}$ & 209.79 & 172.42 & 245.0 & 203.23 & 20.37 & .000 \\
\hline $\begin{array}{l}\text { priority of earnings } \\
\text { over health }\end{array}$ & 178.80 & 216.55 & 216.1 & 218.94 & 8.609 & .035 \\
\hline
\end{tabular}

As the results of the comparative analysis show, entrepreneurs are less convinced that most people consciously and rationally make purchases, choosing the most profitable option in comparison with all groups of employees. Probably, when dealing directly with the manifestations of consumer behavior, observing them every day, entrepreneurs are increasingly convinced that this behavior is rather irrational.

On the other hand, being the buyers of goods and services, entrepreneurs themselves are more satisfied with their purchasing opportunities, which can indicate a higher level of income compared to employees, as well as a freer mindset of the business owners, not limited to fixed wages. This fact is confirmed by the higher level of financial optimism of the entrepreneurs compared to various categories of hired workers. They are more optimistic about the future, believing that their level of income will grow soon.

Entrepreneurs rate themselves as more financially literate people to whom other people seek advice on economic issues. Entrepreneurial activity involves conducting frequent financial transactions and operations, the owner himself often makes financial decisions, apparently, the experience gained allows both the owners and other people to consider entrepreneurs as experts in monetary matters.

Rather natural is the fact that entrepreneurs are more willing to invest in risky projects. Risk is an integral part of business, which is probably why owners are more positive about investing than employees. In addition, this fact may indicate that entrepreneurs are more willing to trust other people, organizations, systems, and they are more aware of investment issues than employees in various fields.

At the same time, the cognitive economic activity of the entrepreneurs is expressed at the average level: it is higher than that of IT specialists, but lower than that of public servants. In general, entrepreneurs strive to be aware of the events of economic and financial life in the country and in the world (they watch news, read modern literature, participate in discussions in forums, etc.), but do not put this as their priority, counting on the experience. Increasing knowledge in the economic sphere becomes relevant only due to a specific task.

It was unexpected that entrepreneurs, in comparison with some categories of employees (school teachers and public servants) lower assess the individual's independent achievements in the economic sphere. Probably setting on independent economic achievements is something common for this group of people, hence the agreement with the statement "I deeply respect and reverence for people who have achieved everything in life by themselves" is at the average level.

Economic ambitions (the desire to have something more than most people) are generally expressed at a high level compared to employees. Only IT professionals are slightly higher than business owners at this indicator. This fact indicates a possible motivation to engage in entrepreneurial activity - not to be "average," to achieve more than an ordinary person. The motivation for entrepreneurial activity explains the fact of the relatively low value of money 
(salary) in comparison with the values of health and vocation. Probably, the ability to earn a lot of money is not an end in itself for business owners, while the desire to do what you love becomes more important.

Interestingly, the conviction of social responsibility of wealth is expressed among entrepreneurs at the average level compared to various categories of employees. For example, the belief that rich people must donate necessarily to charity and help the poor is more shared by school teachers than entrepreneurs, and less by IT professionals. However, in general, business owners tend to agree with the idea of the social responsibility of rich people to the poor, which creates the prerequisites for the sustainable development of society.

The second and final stage of the study was the identification of the structure of economic attitudes of the entrepreneurs. The results of the factor analysis are shown in Table 2.

Table 2. Structure of economic attitudes of the entrepreneurs.

\begin{tabular}{|l|c|c|c|c|}
\hline \multirow{2}{*}{\multicolumn{1}{|c|}{ Indicators }} & \multicolumn{4}{c|}{ Factors } \\
\cline { 2 - 5 } & $\mathbf{1}$ & $\mathbf{2}$ & $\mathbf{3}$ & $\mathbf{4}$ \\
\hline cognitive economic activity & .742 & & & \\
\hline financial literacy & .714 & & & \\
\hline activity and rationality in the banking sector & .657 & & & \\
\hline investment illiteracy & -.493 & & & \\
\hline real estate activity & .468 & .442 & & \\
\hline willingness to invest & .431 & & & \\
\hline economic ambitions & & .794 & & \\
\hline financial optimism & & .690 & -.482 & \\
\hline tendency to savings & & .608 & & \\
\hline significance of financial status & & .502 & & \\
\hline value of independent economic achievements & & .461 & & \\
\hline priority of earnings over vocation & & & .786 & \\
\hline negative attitude to entrepreneurs & & & .557 & \\
\hline consumer activity & .466 & & .503 & \\
\hline priority of earnings over health & & & .405 & \\
\hline consumer satisfaction & & & & .734 \\
\hline confidence in the future through savings & & & & .717 \\
\hline awareness of consumer irrationality & & & & -.453 \\
\hline rationality of purchases & & & & .418 \\
\hline Explainable variance, \% & 16.0 & 10.7 & 9.2 & 8.0 \\
\hline
\end{tabular}

Four factors were identified in the factor analysis, with a certain degree of probability explaining economic behavior strategies and types of the entrepreneurs. The first factor is formed by such attitudes as the desire for cognitive economic activity, financial literacy, activity and rationality in the banking sector, investment illiteracy (with a negative sign), real estate activity, willingness to invest, consumer activity. This factor can be designated as the Strategy of economic activity based on financial knowledge. This strategy meets the main characteristics of the entrepreneur: an active life position, a risk tendency. The combination of these attitudes with financial literacy serves as a solid basis for doing business.

The second factor included the following indicators: economic ambitions, financial optimism, the desire for savings, the significance of financial status, the value of independent economic achievements, real estate activity. This strategy of the economic behavior of the entrepreneurs can be called the High goals strategy, combined with low risk and financial optimism. This is a more restrained strategy in terms of investment, demonstrating the motivation of some owners to achieve high financial goals.

The third factor is formed by such attitudes as economic ambitions (with a negative sign), priority of earnings to vocation, negative attitude to entrepreneurs, consumer activity, priority of earnings to health. Most likely, this factor reflects the so-called "random entrepreneurs," 
who ended up in business not of their own choice, but due to external circumstances. They do not like their activities (there is no identification with entrepreneurs), they do not have significant ambitious goals, they are focused exclusively on making and spending money. This strategy was called Anti-entrepreneurial strategy, or Money-making and spending strategy. It can be assumed that this category of entrepreneurs is a risk group for the implementation of the principles of sustainable development.

The fourth factor included the following attitudes: consumer satisfaction, confidence in the future thanks to savings, awareness of consumer irrationality (with a negative sign), rationality of purchases. This factor probably reflects the Savings and rationality strategy that is inherent quality of individual small business owner. This type of the entrepreneur prefers to accumulate resources rather than invest them, which gives them confidence in the future and satisfaction in the present.

Economic attitudes of social responsibility of wealth, distrust of banks and irrationality did not gain the necessary weight during factorization, and they were excluded from the analysis.

\section{Conclusion}

Thus, the study allows us to conclude about the specifics of economic attitudes of the entrepreneurs compared to employees. Business owners more soberly assess consumer behavior in terms of rationality, they are more inclined to invest, they are more optimistic about their financial future, and they are more competent in financial issues. At the same time, the cognitive economic activity of the entrepreneurs is expressed at the average level, they tend to evaluate the individual's independent achievements in the economic sphere lower, considering this something ordinary.

According to the results of the study, economic ambitions (the desire to achieve high goals), as well as the desire to do what they like, are the motivating factors that push into entrepreneurial activity. At the same time, money itself does not play a significant role in entrepreneurial motivation.

Four main strategies of the economic behavior of the entrepreneurs were identified: a strategy of economic activity based on financial knowledge, a strategy of high goals combined with low risk and financial optimism, a strategy of earning and spending money, a strategy of saving and rationality. At the same time, only the first strategy corresponds to the "classic" ideas about entrepreneurs [e.g., 29], while the rest can be dictated by the increased uncertainty of the external environment and the features of small businesses.

In general, business owners tend to agree with the idea of the social responsibility of rich people to the poor, which creates the prerequisites for the sustainable development of society.

\section{Acknowledgement}

The research was funded by RFBR and Chelyabinsk Region, project number 20-413-740019.

\section{References}

1. D.A. Pletnev, V.I. Barhatov, Procedia - Social and Behavioral Sciences 221 (2016) DOI: 10.1016/j.sbspro.2016.05.105

2. D. Pletnev, E. Nikolaeva, Eurasian Studies in Business and Economics 5 (2017) DOI: 10.1007/978-3-319-46319-3_27

3. A. Lewis, P. Webley, A. Furnham, The new economic mind: the social psychology of economic behavior (Harvester Wheatsheaf, New York, 1995) 
4. O.S. Deyneka, Economical psychology: social-and-political problems (SPbGU, Saint Petersburg, 1999)

5. A.L. Zhuravlev, A.B. Kupreichenko, Bulletin of the practical psychology of education $\mathbf{1}$ (2007)

6. V.P. Poznyakov, Psychological relations and business activity of Russian entrepreneurs (Publishing House of the Institute of Psychology of the Russian Academy of Sciences, Moscow, 2001)

7. T.V. Drobysheva, Economic socialization of personality: a value approach (Publishing House of the Institute of Psychology of the Russian Academy of Sciences, Moscow, 2013)

8. E.D. Dorofeev, Intra-group responsibility in the conditions of joint activity: dis.... Cand. ped. Sciences (Moscow, 1994)

9. Thing Thanh Dang, Attitude to the property of Vietnamese peasants in the context of socio-economic changes: dis.... Candidate of Psychological Sciences (Moscow, 1994)

10. A.L. Zhuravlev, Economic psychology in the context of modern psychological science. Problems of economic psychology (Publishing House of the Institute of Psychology of the Russian Academy of Sciences, Moscow, 2004)

11. A.L. Zhuravlev, A.B. Kupreichenko, Moral and psychological regulation of economic activity (Institute of Psychology of the Russian Academy of Sciences, Moscow, 2003)

12. O.S. Deyneka, Culture and economic behavior: a collection of articles (Maks Press, Moscow, 2011)

13. M. Rokeach, The Nature of Attitudes. International Encyclopedia of the Social Sciences (D.L. Sills, Crowell, 1986)

14. M.B. Smith, Attitude Change. International Encyclopedia of the Social Sciences (D.L. Sills, Crowell, 1986)

15. L.D. Dinauer, E.E. Fink, Human Communication Research 31 (2005) DOI: 10.1111/j.1468-2958.2005.tb00863.x

16. M. Conner, P. Sparks, European Review of Social Psychology 12 (2002) DOI: $10.1080 / 14792772143000012$

17. A. Kalil, H.A. Schweingruber, K.S. Seefeldt, American Journal of Community Psychology 29(5) (2001) DOI: 10.1023/A:1010413101010

18. A. Furnham, Journal of Applied Social Psychology 15(5) (1985) DOI:10.1111/j.15591816.1985.tb00912.x

19. A.J. Mewse, S.E.G. Lea, W. Wrapson, Journal of Economic Psychology 31(6) (2010)

20. S. Von Stumm, M. Fenton O'Creevy, A. Furnham, Personality and Individual Differences 54(3) (2013) DOI: 10.1016/j.paid.2012.09.019

21. G. Antonides, N.L. Van Der Sar, Journal of Economic Psychology 11(2) (1990) DOI: 10.1016/0167-4870(90)90005-T

22. E. Zabelina, O. Deyneka, D. Tsiring, International Journal of Entrepreneurial Behavior \& Research 25(8) (2019) DOI:10.1108/IJEBR-04-2018-0224

23. V.A. Khashchenko, Experimental psychology 4(1) (2011)

24. D.C. Croson, M. Minniti, Journal of Economic Psychology 33 (2012) DOI: 10.1016/j.joep.2011.05.001

25. E. Zabelina, D. Tsiring, Yu. Chestyunina, International Entrepreneurship and Management Journal 14(1) (2018) DOI: 10.1007/s11365-018-0502-y 
26. R.A. Baron, B.A. Mueller, M.T. Wolfe, Journal of business venturing 31(1) (2016) DOI: 10.1016/j.jbusvent.2015.08.002

27. F.H. Wijbenga, A. Van Witteloostuijn, Journal of Economic Psychology 28 (2007) DOI:10.1016/j.joep.2007.04.003

28. K.E. Warneryd, The Psychology of Innovative Entrepreneurship. Handbook of Economic Psychology (Dodrechtj Boston, London, 1988)

29. M. Ali, I. Ali, K.A. Al-Maimani, K. Park, Journal of Innovation \& Knowledge 3(3) (2018) DOI: 10.1016/j.jik.2017.03.007

30. J.A. Shumpeter, The Theory of Economic Development. An Inquiry into Profits. Capital, Credit, Interest, and the Business Cycle (Cambridge, 1934) https://www.researchgate.net/publication/228247192_The_Theory_of_Economic_Dev elopment_An_Inquiry_Into_Profits_Capital_Credit_Interest_and_the_Business_Cycle. 